\title{
DISEMINASI BAHAN AJAR IPA BERVISI SETS
}

\author{
Ummu Jauharin Farda dan Ersila Devy Rinjani \\ Prodi Pendidikan Guru Madrasah Ibtidaiyah, Fakultas Agama Islam \\ Universitas Wahid Hasyim Semarang \\ jaufaummu91@gmail.com
}

\begin{abstract}
Abstrak
Penelitian ini bertujuan untuk mendiseminikasikan pengembangan bahan ajar cetak IPA bervisi SETS yang memenuhi kriteria valid dan efektif. Metode penelitian yang digunakan dalam penelitian ini Research and Development (R\&D) dari empat tahap yang disederhanakan menjadi tiga tahap, yaitu; (1) pendefinisian (define), (2) perancangan (design), dan (3) pengembangan (development). Subyek penelitian ini siswa kelas IV SDN Kalibanteng Kidul 03. Teknik pengumpulan data menggunakan wawancara, tes, observasi, angket. Teknik analisis data menggunakan analisis deskriptif kualitatif dan kuantitatif. Karakteristik bahan ajar cetak IPA bervisi SETS adalah menggabungkan antara materi sumber daya alam dengan unsur-unsur Science, Environment, Technology, and Society. Hasil pengembangan bahan ajar cetakvalid dan efektif. Skor validasi dalam kategori sangat baik. Skor keefektifan bahan ajar cetak terlihat dari hasil belajar, ketuntasan hasil belajar, peningkatan hasil belajar, aktivitas guru dan aktivitas peserta didik. Berdasarkan hasil dan pembahasan dalam penelitian pengembangan pembelajaran IPA SD bervisi SETS, disarankan; bahan ajar cetak IPA bervisi SETS dalam kompetensi sumber daya alam telah dikembangkan dengan hasil valid dan efektif, maka perlu dilakukan uji coba dalam skala lebih luas dan guru dapat menggunakan bahan ajar cetak IPA bervisi SETS sebagai suplemen untuk proses pembelajaran.
\end{abstract}

Kata Kunci: Diseminasi, Bahan Ajar IPA, Visi SETS

Abstract

The goal of this research is to disseminate the improvement of IPA printed teaching material in Science, Environment, Technology, Society (SETS) vision which fulfill valid criteria and effective. The method in this research is Research and Development $(R \& D)$. Actually it has four steps but we simplify it become three steps, they are define, design, and development $(R \& D)$. Actually it has 4 steps but we simplify become 3 steps, they are devine, design, and development. The subject of this research is fourth grader student of SDN kalibanteng kidul 03. The technique of data collection using interview, test, observation, questionnaire. The characteristic of IPA printed teaching material in sets vision is combining between natural science material with elements of science, environment, technology, and 
society. The result of printed teaching material is valid and effective. Validation score in very good category. The effectiveness score of printed teaching material can be seen in learning result, learning complitenees, learning improvement, teacher and student activity. Based on the result and discussion in the research of learning improvement of IPA in SETS vision in natural resource, competence already improved with valid and effective result, so it need to be tried in wider scale and teacher can used IPA printed mterial in SETS vision as suplement for learning process.

Keywords: dissemination, IPA teaching material, SETS vision

\section{A. PENDAhuluan}

Dunia pendidikan saat ini dituntut menghadapi tantangan perkembangan zaman yang secara kualitatif cenderung meningkat. Pendidikan IPA sebagai bagian dari pendidikan umumnya memiliki peran penting dalam peningkatan mutu pendidikan, khususnya di dalam menghasilkan peserta didik yang berkualitas. Prinsip psikologi pendidikan adalah bahwa guru tidak begitu saja memberikan pengetahuan kepada peserta didik, tetapi peserta didiklah yang harus aktif membangun pengetahuan dalam pikiran mereka sendiri. ${ }^{1}$ Kegiatan belajar mengajar di sekolah dasar guru harus menyesuaikan bahan ajarnya dengan Kurikulum 2013.

Bahan ajar adalah segala sesuatu yang dapat digunakan untuk menyalurkan pesan (materi pelajaran), merangsang pikiran, dan perasaan, perhatian dan kemampuan peserta didik, sehingga dapat mendorong proses pembelajaran. ${ }^{2}$ Materi pelajaran yang sangat teknis dengan istilah terlalu banyak untuk dihafal secara rinci akan membuat peserta didik sering merasa mengantuk. Buku bahan ajar yang ada tidak menarik bagi peserta didik maka dapat membuat pembelajaran yang berlangsung kurang menarik bagi peserta didik.

Buku bahan ajar sebaiknya mengaitkan pembelajaran dengan konsep kontekstual, dengan kata lain buku bahan ajar sebaiknya harus terkait dengan konsep

\footnotetext{
${ }^{1}$ Esa Nur Wahyunidan Baharuddin. Teori Belajar \& Pembelajaran. Jogjakarta: Ar-Ruzz Media. 2010. hlm. 115.

2 Rusman. Model-Model Pembelajaran. Jakarta: Rajawali Press. 2010.
} 
ilmu dan lingkungan selain itu ditunjang dengan gambar dan tampilan yang menarik yang disusun untuk sebuah proses pembelajaran yang efektif. ${ }^{3}$ Kolaborasi antar unsur materi dengan lingkungan jika tidak sesuai akan mempengaruhi kebermaknaan pembelajaran bagi peserta didik. Kolaborasi yang tidak sesuai dengan dan unsurunsur aktif dilingkungan bisa sangat mempengaruhi proses kebermaknaan belajar dalam pembelajaran, mempengaruhi kognitif dan metakognitif karakteristik proses itu sendiri. ${ }^{4}$

Bahan ajar merupakan salah satu sumber belajar, yakni segala sesuatu yang memudahkan peserta didik memperoleh sejumlah informasi pengetahuan, pengalaman, dan keterampilan dalam proses belajar mengajar. Sedangkan pemilihan bahan ajar berpendekatan SETS adalah berdasarkan faktor kebutuhan bahan ajar yang masih sangat minim dan kurang variatif, dengan menggunakan bahan ajar berpendekatan SETS diharapkan peserta didik memahami konsep yang disampaikan dan memahami dampak dari proses yang dipelajari baik bagi lingkungan maupun bagi dirinya sendiri.

Penyusunan bahan ajar ini akan berpengaruh pada kompleks tidaknya materi ajar yang diperoleh peserta didik dalam setiap pembelajarannya, maka perlu pengembangan bahan ajar yang sesuai dengan standar isi dan kontekstual. Khususnya bahan ajar IPA perlu mengkaitkan dengan lingkungan sekitar, masyarakat, dan teknologi agar peserta didik tidak hanya memahami sainsnya saja akan tetapi mengaplikasikannya pada kehidupan sehari-hari. Pengkaitan ini lebih dikenal dengan pembelajaran IPA bervisi Science, Environment, Technology, And Society (SETS). SETS memberi peluang untuk mempelajari hakikat sains, teknologi, dan keterkaitannya dengan lingkungan dan masyarakat. Secara mendasar dapat dikatakan bahwa melalui pendekatan SETS diharapkan peserta didik memiliki kemampuan

\footnotetext{
${ }^{3}$ Rosario, B. I., Science, Technology, Society, dan Evironment (STSE). Approach in Environment Science For Non Science Student in

${ }^{4}$ Viola, S. R., giretti, A., \&leo, T. Detecting Differences in "Meaningful Learning" Behaviours and their Evaluation: a Data Driven Approach. International Journal of Computing \& Information Science.2007. 5 (2) : 63-73.
} 
memandang sesuatu secara terintegrasi dengan memperhatikan keempat unsur SETS, sehingga memperoleh pemahaman yang mendalam tentang pengetahuan yang dimiliki. $^{5}$

IPA di Sekolah Dasar bertujuan agar peserta didik memiliki kemampuan sebagai berikut; (1) Memperoleh keyakinan terhadap Tuhan Yang Maha Esa berdasarkan keberadaan, keindahan dan keteraturan alam ciptaan-Nya, (2) Mengembangkan pengetahuan dan pemahaman konsep-konsep IPA yang bermanfaat dan dapat diterapkan dalam kehidupan sehari-hari, (3) Mengembangkan rasa ingin tahu, sikap positif dan kesadaran tentang adanya hubungan yang saling mempengaruhi; antara IPA, lingkungan, teknologi dan masyarakat, (4) Mengembangkan keterampilan proses untuk menyelidiki alam sekitar, memecahkan masalah dan membuat keputusan, (5) Meningkatkan kesadaran untuk berperan serta dalam memelihara, menjaga dan melestarikan lingkungan alam, (6) Meningkatkan kesadaran untuk menghargai alam dan gejala keteraturannya sebagai salah satu ciptaan Tuhan, (7) Memperoleh bekal pengetahuan konsep dan keterampilan IPA sebagai dasar untuk melanjutkan pendidikan SMP/MTs. ${ }^{6}$

Pada dasarnya dalam kehidupan manusia, unsur sains, lingkungan, teknologi, dan masyarakat itu saling berkaitan satu sama lainnya. Hal tersebut menguatkan pernyataan bahwa peserta didik belajar sebagai bekal hidup di masyarakat.Peserta didik harus hidup bermasyarakat dan sebagai bagian dari masyarakat harus berinteraksi dengan alam. Dari pembelajaran peserta didik mengenal konsep alam yang selanjutnya dikenal dengan sains dan dimanfaatkan untuk memenuhi kebutuhannya dalam bentuk teknologi untuk memperoleh kemudahan atau kemanfaatan dalam proses kehidupan individu maupun masyarakat.

Melalui penelitian ini diharapkan pembelajaran tentang materi sumber daya alam dapat membantu peserta didik mengaplikasikan pemahaman konsepnya dalam

\footnotetext{
${ }^{5}$ Achmad Binadja. Hakekat dan Tujuan Pada SETS (Science, Environment, Technology, And Society) Dalam Konteks Kehidupan Pendidikan Yang Ada. Semarang: UNNES. 1999.

${ }^{6}$ Depdiknas. Kurikulum Tingkat Satuan Pendidikan (KTSP). Jakarta:Departemen Pendidikan Nasional. 2006. hlm. 6.
} 
dunia nyata, dan benar-benar memahami fenomena-fenomena yang terjadi dalam lingkungan serta mampu memahami lingkungan tempat tinggal peserta didik sangat bermanfaat bagi kehidupannya serta mengaplikasikan hasil dari pemerolehan pengetahuannya, yang tentu saja masih dengan bimbingan guru. Melalui kegiatan pembelajaran diharapkan peserta didik diajak berpikir kritis sejak dini, dalam keadaan seperti apapun.

Bahan ajar bervisi SETS yang telah disusun dan telah teruji kefektifannya sangat penting untuk disebarluaskan guna mengobati permasalahan yang sama. Pentingnya sebuah diseminasi bahan ajar IPA bervisi SETS bertujuan agar peserta didik memperoleh informasi sehingga timbul kesadaran untuk bisa memanfaatkan informasi yang didapat. Diseminasi adalah sebuah proses penyebarluasan informasi dan inovasi yang telah direncanakan, diarahkan, dan dikelola. Sebuah diseminasi bahan ajar bervisi SETS merupakan inovasi dalam bidang pendidikan yang bertujuan menyebarluaskan informasi untuk bisa diterima dan disesuaikan dnegan kondisi tertentu sehingga memudahkan dalam proses pembelajaran dan dapat memecahkan persoalan yang berhubungan dengan penyampaian materi IPA.

Harapannya adalah menimbulkan kesadaran bagi pengguna untuk bisa menerima, menerapkan dan pada akhirnya memanfaatkan informasi yang diterima. Dalam hal ini diseminasi diterapkan di SDN Kalibanteng 03 Semarang yang merupakan salah satu SD inklusi di Semarang. Selain SDN Kalibanteng 03 Semarang, ada beberapa SD inklusi yang kedepannya dapat menjadi target diseminasi berikutnya, sekolah-sekolah tersebut adalah SDN Bulusan Tembalang, SD Hj. Isriati Baiturrahman, SD Barusari 02, SD Kalibanteng Kidul, SD Kalicari 03, SD Jomblang 02, SD Candi 04, SDN Taman Pekunden, SD Kalicari 02, SD Kalicari 01, dan masih banyak SD inklusi lainnya.

Berdasarkan pengamatan yang dilakukan oleh peneliti khususnya di SDN Kalibanteng 03 Semarang, bahwasanya SETS sebagai pendekatan pembelajaran yang menghubungkaitkan lingkungan, teknologi, dan masyarakat, pendekatan ini sudah dikenal tetapi belum sepenuhnya diimplementasikan. Materi pembelajaran IPA 
sumber daya alam adalah materi yang berhubungan dengan alam dan kehidupan sehari-hari. Permasalahan yang lain adalah prioritas pembelajaran pada target selesainya semua materi pelajaran tanpa menghubungkan materi dengan kehidupan sehari-hari peserta didik, serta manfaat peserta didik mempelajari materi tersebut sehingga mengakibatkan hasil belajar peserta didik rendah. Permasalahan yang ditemukan selanjutnya adalah minimnya upaya guru sekolah dasar untuk mengembangkan bahan ajar yang baik. Hal ini menjadi permasalahan klasik, dan perlu upaya pemecahan yang bersifat dorongan serta motivasi dari berbagai pihak. Tidak ada salahnya apabila guru mencoba sesuatuhal yang baru dengan mengembangkan bahan ajar yang memenuhi kriteria bahan ajar kelas IV Sekolah Dasar.

Permasalahan yang ditemukan di lapangan adalah terdapatnya anak berkebutuhan khusus dengan jenis keunikannya adalah slow learner atau lamban belajar. Data Kementerian Sosial Republik Indonesia menyebutkan bahwa pada tahun 2011 kurang lebih 7 juta orang atau sekitar 3\% dari jumlah total seluruh penduduk Indonesia adalah anak berkebutuhan khusus. Sebagian besar dari jumlah tersebut adalah anak lamban belajar (slow learner), autis, dan tunagrahita. ${ }^{7}$

Slow learner adalah peserta didik yang mengalami keterlambatan dalam belajar. Anak Slow learner membutuhkan waktu yang lebih lama dalam belajar dibandingkan peserta didik lain yang memiliki potensi intelektual yang sama. Anak slow learner secara fisik tidak berbeda dengan anak normal yang lain, mereka pun memori otak dan akal sehat yang berfungsi secara normal pada sebagian besar situasi. Kondisi inilah yang membuat guru dan orang tua kesulitan dalam mengidentifikasi keunikan dalam kebutuhan khususnya. Namun, satu hal yang perlu diperhatikan lebih adalah anak slow learner tidak memiliki kemampuan dalam melaksanakan tugastugas sekolah karena keterbatasan IQ mereka.

\footnotetext{
${ }^{7}$ Hasyim Yachya. Tentang Anak Berkebutuhan Khusus. Jakarta. 2013.
} 
Anak slow learner dapat dipahami pula sebagai anak yang memiliki potensi intelektual lebih rendah dibawah anak normal namun lebih tinggi dari anak pengidap tunagrahita. Mereka mengalami keterlambatan dalam berpikir, beradaptasi, dan merespon rangsangan yang muncul. Mereka membutuhkan waktu yang lebih lama untuk dapat menyelesaikan tugas sekolah baik akademik maupun non-akademik. Penjelasan harus diberikan secara berulang-ulang hingga anak benar-benar memahami. Oleh karena itu anak slow learner membutuhkan pelayanan pendidikan khusus. ${ }^{8}$

Beberapa sekolah dasar di Semarang menerapkan pendidikan inklusi yang mana beberapa peserta didiknya adalah anak berkebutuhan khusus, namun anak berkebutuhan yang dimaksud masih dalam taraf ringan, salah satunya adalah pengidap slow learner. Dalam hal ini diseminasi diterapkan di SDN Kalibanteng 03 Semarang yang merupakan salah SD inklusi di Semarang. Selain SDN Kalibanteng 03 Semarang, ada beberapa SD inklusi yang kedepannya dapat menjadi target diseminasi berikutnya, sekolah-sekolah tersebut adalah SDN Bulusan Tembalang, SD Hj. Isriati Baiturrahman, SD Barusari 02, SD Kalibanteng Kidul, SD Kalicari 03, SD Jomblang 02, SD Candi 04, SDN Taman Pekunden, SD Kalicari 02, SD Kalicari 01, dan masih banyak SD inklusi lainnya.

Dari permasalahan di atas, maka diperlukan pemecahan agar dapat meminimalisir masalah yang muncul dalam proses pembelajaran, salah satunya dengan pengembangan bahan ajar IPA bervisi SETS. Bahan ajar kelas IV Sekolah Dasar yang dikembangkan akan menjadi sumber dan acuan penting bagi peserta didik.Berdasarkan dari latar belakang di atas, maka penulis tertarik untuk melakukan penelitian yang berjudul "Pengembangan Bahan Ajar IPA Bervisi SETS dalam Kompetensi Sumber Daya Alam Kelas IV Sekolah Dasar".Tujuan penelitian ini adalah menghasilkan bahan ajar cetak IPA bervisi SETS dalam kompetensi sumber daya alam untuk kelas IV Sekolah Dasar.

\footnotetext{
${ }^{8}$ Wachyu Amelia," Karakteristik dan Jenis Kesulitan Belajar Anak Slow Learner" dalam Jurnal Ilmu Kesehatan Aisyah, volume 1 no. 2 (Juli - Desember, 2016), hal 55
} 
Secara terperinci tujuan penelitian ini sebagai berikut: (1) Menjelaskan karakteristik bahan ajar IPA bervisi SETS yang dikembangkan dalam kompetensi sumber daya alam untuk kelas IV Sekolah Dasar. (2) Memvalidasi bahan ajar IPA bervisi SETS yang dikembangkan dalam kompetensi sumber daya alam untuk kelas IV Sekolah Dasar. (3) Mengetahui apakah bahan ajar IPA bervisi SETS yang dikembangkan efektif membantu peserta didik mencapai kompetensi yang ditetapkan dalam kurikulum.

\section{B. METODE PENELITIAN}

Metode penelitian yang digunakan dalam penelitian ini Research and Development (R\&D). Produk yang dikembangkan dan diuji dalam penelitian ini adalah buku teks bahan ajar cetak yang berisi materi ajar IPA bervisi SETS kelas IV Sekolah Dasar semester 2. Prosedur penelitian menggunakan model 3-D (three D model). Model 3-D terdiri dari tiga tahap, yaitu: (1) pendefinisian (define), (2) perancangan (design), dan (3) pengembangan (development).

Langkah-langkah yang ditempuh dalam pembuatan produk dan pengembangan buku teks bahan ajar cetak yang berisi materi ajar IPA bervisi SETS kelas IV Sekolah Dasar semester 2 dalam research and development yang dimodifikasi oleh Borg and Gall (1983) sebagai berikut: 


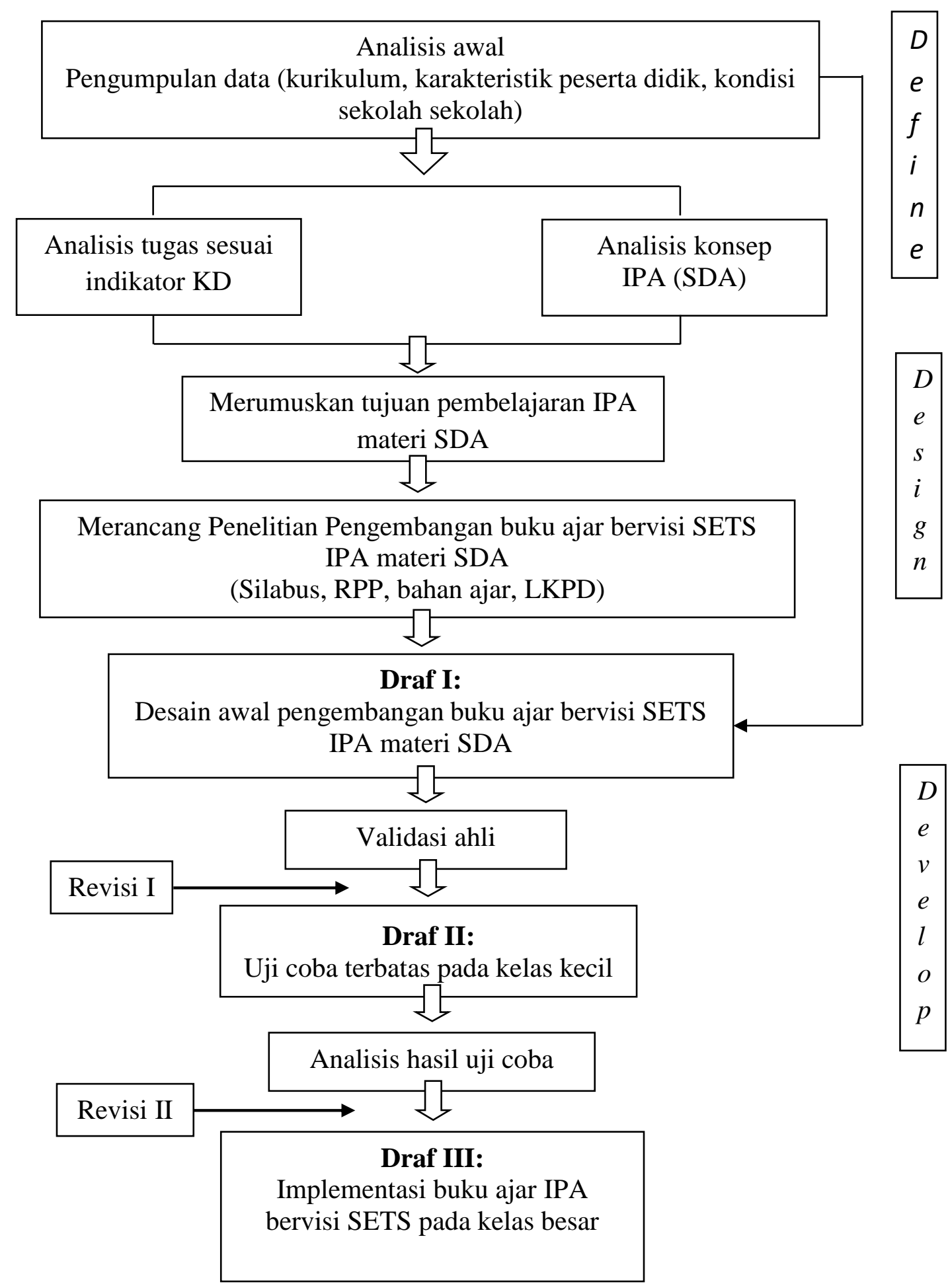

Gambar 1. Bagan desain penelitian r 2 Desember 2018 


\section{HASIL DAN PEMBAHASAN}

\section{Hasil Penelitian}

Penelitian ini adalah penelitian pengembangan menggunakan model pengembangan Four-D atau 4-D yaitu define (pendefinisian/penetapan), design (perancangan), develope (pengembangan) dan disseminate (penyebaran). Dalam penelitian ini hanya digunakan tiga tahap yaitu define, design dan develope, sedangkan desemination tidak. Penelitian dan pengembangan ini bertujuan untuk menghasilkan bahan ajar cetak IPA bervisi SETS pada materi sumber daya alam yang valid, efektif, dan praktis.

\section{a. Tahap Define (Pendefinisian)}

Hasil dari tahap define berdasarkan wawancara menunjukkan bahwa hasil belajar peserta didik rendah. Permasalahan yang lain guru masih minim untuk mengembangkan bahan ajar yang baik. Hasil pengamatan analisis kebutuhan terhadap pengembangan bahan ajar cetak IPA bervisi SETS dalam kompetensi sumber daya alam kelas IV Sekolah Dasar bahwa guru belum menggunkan silabus, RPP, LKPD dan bahan ajar bervisi SETS.

\section{b. Tahap Design (Desain)}

Hasil analisis awal diketahui belum adanya bahan ajar cetak yang mengimplementasikan unsur-unsur SETS pada bahan ajar cetak. Langkahlangkah dalam mendesain bahan ajar adalah; 1) menentukan judul, 2) merancang petunjuk belajar, 3) menentukan kompetensi dasar dan indikator, 4) mendesain konten isi bahan ajar, 5) mendesain konten-konten pendukung, 6) menyusun latihan-latihan soal, 7) mendesain petunjuk kerja, 8) menyusun glosrium dan 9) menyusun evaluasi.Langkah selanjutnya adalah menyusun 1) instrument validasi bahan ajar cetak, 2) instrumen data keefektifan bahan ajar cetak yang terdiri dari; a) soal tes dan b) lembar pengamatan aktivitas peserta didik, 3) instrumen data kepraktisan bahan ajar terdiri dari; a) instrumen 
respons guru dan b) respons peserta didik berupa skala Likert. Bahan ajar cetak yang sudah didesain sesuai dengan lembar validasi bahan ajar cetak, selanjutnya peneliti menentukan validator.

\section{c. Tahap Develop (Pengembangan)}

Tahap develop terdiri dari; 1) validasi bahan ajar cetak oleh pakar diikuti dengan revisi, 2) Uji coba terbatas, hasilnya sebagai dasar revisi dan 3) uji coba lebih lanjut pada kelas yang sesungguhnya.

\section{Pembahasan}

Penelitian ini bertujuan untuk menghasilkan bahan ajar cetak IPA Bervisi SETS dalam Kompetensi Sumber Daya Alam Kelas IV Sekolah Dasar yang valid, efektif dan praktis. Bahan ajar yang dikembangkan mengimplementasikan unsur-unsur SETS (science, environment, technology and society). Tahap design peneliti merancang strategi pembelajaran dan menyusun instrument-instrumen yang dibutuhkan dalam penelitian. Strategi pembelajaran yang digunakan adalah strategi pembelajaran yang mengimplementasikan visi SETS.

Langkah selanjutnya adalah mendesain bahan ajar cetak yang mengimplementasikan SETS. Bahan ajar cetak disusun agar peserta didik mengetahui dan mampu mengaplikasikan dalam kehidupan sehari-hari. Informasi dan konten-konten materi dibuat menarik, mudah dipahami dan dapat dipelajari peserta didik. Bahan ajar cetak yang dikembangkan menyediakan konten-konten yang mudah dipelajari peserta didik.

Disediakan juga petunjuk penggunaan buku agar peserta didik mudah menggunakannya. Pada bagian akhir bahan ajar cetak tersedia konten glosarium atau kamus kecil yang berisi istilah-istilah penting. Ukuran bahan ajar cetak didesain agar peserta didik mudah membawanya dan mudah dimasukan kedalam tas. Bahan ajar dicetak menggunakan kertas B5 (17,6 cm x $25 \mathrm{~cm}$ ) yang terdiri dari 73 halaman. 


\section{a. Kevalidan bahan ajar cetak IPA bervisi SETS}

Kevalidan bahan ajar cetak bervisi SETS dilihat dari hasil validasi ahli dan kepraktisannya. Kepraktisan bahan ajar cetak diperoleh dari tanggapan atau respons guru dan respons peserta didik. Bahan ajar cetak yang dikembangkan divalidasi dan diujicobakan untuk mengetahui sebarapa valid bahan ajar cetak yang telah dikembangkan. Hasil validasi bahan ajar cetak yang dilakukan oleh 3 orang akademisi dan satu orang praktisi menunjukkan skor validasi 45; 44; 43; dan 45 jika dikonsultasikan pada tabel kriteria validitas bahan ajar cetak dalam kategori sangat baik. Keempat skor validasi bahan ajar cetak jika dirata-rata diperoleh skor nilai validasi 44 atau dalam kategori sangat baik. Hasil pengembangan bahan ajar cetak terdapat beberapa masukan dari validator, diantaranya 1) bagian huruf masih ada yang tampak kecil, 2) tabel harus diberi nomer, 3) redaksi agar disesuaikan dengan EYD, 4) gambar diperjelas, 5) tujuan dan indikator perlu diperbaiki ditampilan awal, 6) setiap kata asing diberi terjemahan dalam Bahasa Indonesia.

Hasil validasi menunjukkan skor dalam kategori sangat baik, selanjutnya bahan ajar cetak diujicobakan di kelas ujicoba, dan kelas eksperimen. Kelas ujicoba untuk mengetahui seberapa valid dan reliable instrument yang digunakan dalam penelitian. Hasil uji coba terhadap instrument tes menunjukkan 30 soal valid dan reliable sehingga dapat digunakan dalam penelitian. Uji coba lapangan terhadap bahan ajar cetak dilaksanakan dengan cara mengajarkan materi sumber daya alam menggunakan bahan ajar cetak bervisi SETS. Binadja (1999a) yaitu: 1) pembelajaran konsep IPA (sains) tetap diberikan; 2) peserta didik dibawa ke situasi untuk melihat teknologi yang terkait; 3) peserta didik diminta untuk menjelaskan keterhubungkaitan antara unsur sains yang dibincangkan dengan unsur-unsur lain dalam SETS. 
Kepraktisan bahan ajar cetak dapat dilihat dari tanggapan atau respons peserta didik dan respons guru. Instrument yang digunakan untuk mengetahui kepraktisan adalah lembar angket respons guru dan angket respons peserta didik. Hasil respons guru terhadap bahan ajar cetak menunjukkan skor 18 kategori sangat baik, karena terdapat dua respons negative dari dua puluh indikator atau skor 18 berada di dalam rentang (15 $\leq \mathrm{Sa} \leq 20)$ dengan kategori sangat baik.

Hasil respons peserta didik terdapat tiga kategori, yaitu 25 peserta didik kategori sangat baik, 3 peserta didik kategori baik dan 2 peserta didik kategori cukup. Respons peserta didik jika dikonsultasikan pada indikator keberhasilan penelitian diperoleh hasil/ kategori berhasil karena terdapat 25 peserta didik yang memberikan respons sangat baik terhadap pengembangan bahan ajar cetak IPA bervisi SETS terkait kompetensi sumber daya alam kelas IV Semester II.

Hasil analisis analisis respons peserta didik menunjukkan terdapat 2 skor di bawah kriteria ketuntasan yaitu indikator 19 dengan kategori baik dan indikator 15 dengan kategori cukup. Jumlah indikator dalam kategori sangat baik sebanyak 24 indikator. Hasil pengembangan bahan ajar cetak bervisi SETS kategori praktis. Sejalan dengan penelitian yang dilakukan oleh Wijayama, Pengembangan Perangkat Pembelajaran IPA Bervisi SETS dengan Pendekatan SAVI untuk Meningkatkan Keefektifan Pembelajaran dan Pembentukan Karakter Peserta Didik Sekolah Dasar. Hasil penelitian menunjukkan respons guru dan respons peserta didik 95,65\% dan 92,5\% dengan kategori sangat baik. ${ }^{9}$

Hasil penelitian membuktikan bahwa peran pendekatan SETS dalam pengembangan bahan ajar sangat signifikannifikan. SETS terbukti

\footnotetext{
${ }^{9}$ Bayu Wijayama,Pengembangan Perangkat Pembelajaran IPA Bervisi SETS dengan Pendekatan SAVI untuk Meningkatkan Keefektifan Pembelajaran dan Pembentukan Karakter Peserta Didik Sekolah Dasar, Tesis,Semarang: Program Pascasarjana Unnes.
} 
mempermudah guru dalam mengajar yang ditunjukkan dengan respons guru sangat baik dan respons peserta didik dalam kategori baik.

\section{b. Keefektifan bahan ajar cetak IPA bervisi SETS}

Keefektifan bahan ajar cetak dapat dilihat dari hasil belajar, peningkatan hasil belajar, aktivitas guru dan aktivitas peserta didik. Instrument yang digunakan untuk mengukur hasil belajar dan peningkatan hasil belajar adalah soal tes. Hasil belajar dianalisis menggunakan uji one sample $t$ test sedangkan peningkatan hasil belajar dianalisis menggunakan uji $\mathrm{N}$ <gain>. Kriteria keberhasilan jika terdapat paling sedikit 23 peserta didik yang tuntas atau memperoleh skor di atas KKM, yaitu 70 dan peningkatan hasil balajar pada kategori sedang. Aktivitas guru dan aktivitas peserta didik diperoleh dari instrument lembar pengamatan aktivitas guru dan peserta didik. Aktivitas guru dan aktivitas peserta didik dianalisis menggunakan statistik deskritif yang kemudian dikonsultasikan dengan indikator pada instrument tersebut. Aktivitas peserta didik dikatakan berhasil jika setidaknya terdapat 23 peserta didik dalam kategori tinggi.

Analisis hasil belajar peserta didik menunjukkan perolehan nilai pretest terdapat 9 dari 30 peserta didik yang memperoleh nilai $>70$. Ketuntasan hasil belajar pretest kelas kontrol terdapat 8 dari 30 peserta didik yang memperoleh nilai $>70$. Hasil uji data pretest dapat diketahui bahwa data berdistribusi normal, homogen dan tidak ada perbedaan antara kelas eksperimen, dengan demikian dapat diketahui kedua kelas pada awal penelitian memiliki kemampuan yang sama. Hasil uji normalitas menunjukkan nilai Signifikan. kelas kontrol dan kelas eksperimen pada kolom Kolmogorov-Smirnov a adalah 0,200 dan 0,82 jika di konsultasikan dengan $\alpha=0,05$ maka nilai Signifikan. kelas kontrol $=0,82>\alpha=0,05$ dan nilai Signifikan kelas eksperimen $=0,200>\alpha=0,05$ sehingga dapat 
disimpulkan data berdistribusi normal. Hasil uji homogenitas data pretest menunjukkan perolehan nilai signifikan $0,235>\alpha=0,05$ yang berarti kedua kelas, yaitu kelas eksperimen dan kelas kontrol memiliki variansi yang sama atau identik.

Hasil uji asumsi dasar (uji normalitas dan homogenitas) dijadikan dasar untuk melakukan uji beda rata-rata (independent sample test) untuk mengetahui kedua kelas memiliki perbedaan atau tidak. Uji t dilakukan untuk mengetahui ketuntasan hasil belajar. Hasil uji one sample t test menunjukkan harga $t_{\text {hitung }} 6,74>\mathrm{t}_{\text {table }}=1,729$ dengan demikian $\mathrm{H}_{0}$ diterima dan $\mathrm{H}_{\mathrm{a}}$ ditolak. Jadi dapat disimpulkan bahwa jumlah peserta didik yang memperoleh skor 70 adalah benar. Analisis selanjutnya adalah analisis data postest. Langkah analisis terhadap data postest, yaitu menentukan kedua kelas berdistribusi normal dan memiliki variansi yang sama dengan uji asumsi dasar uji normalitas dan uji homogenitas, selanjutnya untuk mengetahui perbedaan hasil belajar dilakukan uji independent sample test.

Hasil uji normalitas menunjukkan nilai Signifikan. kelas kontrol dan kelas eksperimen pada kolom Kolmogorov-Smirnov a adalah 0,165 dan 0,158 jika di konsultasikan dengan $\alpha=0,05$ maka nilai Signifikan. kelas kontrol $=0,165>\alpha=0,05$ dan nilai Signifikan kelas eksperimen $=$ $0,158>\alpha=0,05$ sehingga dapat disimpulkan data berdistribusi normal. Uji homogenitas menunjukkan perolehan nilai signifikan $0,235>\alpha=0,05$ yang berarti kedua kelas, yaitu kelas eksperimen dan kelas kontrol memiliki variansi yang sama atau identik. Hasil uji perbedaan data postest menunjukkan perolehan Signifikan. (2-tailed) 0,000 < 0,05 sehingga dapat disimpulkan hasil uji beda rata-rata pada data postest menunjukkan bahwa kemampuan peserta didik kelas kontrol dengan kelas eksperimen berbeda atau tidak sama. 
Ketuntasan hasil belajar kelas eksperimen menunjukkan nilai terendah 57 nilai tertinggi 90 nilai rata-rata 79 dan jumlah peserta didik yang tuntas (KKM 70) sebanyak 26 peserta didik. Data ketuntasan hasil belajar kelas kontrol menunjukkan menunjukkan nilai terendah 47 nilai tertinggi 87 nilai rata-rata 70 dan jumlah peserta didik yang tuntas (KKM 70) sebanyak 17 peserta didik. Analisis ketuntasan hasil belajar dapat dikatakan tuntas karena jumlah peserta didik yang tuntas pada kelas eksperimen $26>23$. Uji ketuntasan hasil belajar menggunakan one sample t test. Uji t dilakukan untuk mengetahui ketuntasan hasil belajar. Hasil uji one sample $\mathrm{t}$ test menunjukkan harga thitung 6,74> $\mathrm{t}_{\text {table }}=1,729$ dengandemikian $\mathrm{H}_{0}$ diterima dan $\mathrm{H}_{\mathrm{a}}$ ditolak. Jadi dapat disimpulkan bahwa jumlah peserta didik yang memperoleh skor 70 adalah benar.

Peningkatan hasil belajar kedua kelas diukur menggunakan uji $\mathrm{n}$ <gain>. Hasil uji peningkatan hasil belajar kelas eksperimen diperoleh skor $\langle\mathrm{g}\rangle=0,40$ dalam kategori sedang dan kelas kontrol $\langle\mathrm{g}\rangle=0,15$ dalam kategori rendah. Peningkatan hasil belajar dikatakan berhasil jika diperoleh skorpaling tidak dalam kategori sedang. Hasil uji keefektifan bahan ajar cetak dapat disimpulkan efektif, dapat dilihat dari uji hasil belajar terdapat 23 peserta didik yang tuntas, skor gain 0,40 dala kategori sedang dan uji one sample $t$ test menunjukkan $t_{\text {hitung }} 6,74>t_{\text {table }}=1,729$. Indikator keefektifan selanjutnya adalah aktivitas peserta didik.

Aktivitas peserta didik adalah perilaku yang nampak diamati ketika kegiatan penelitian. Hasil pengamatan aktivitas peserta didik yang memperoleh skor dalam kategori tinggi pada pertemuan I sebanyak 28, pertemuan II sebanyak 29 dan pertemuan III sebanyak 29. Hasil pengamatan aktivitas peserta didik menunjukkan skor sangat tinggi sejalan dengan ciri atau karakteristik pembelajaran bervisi SETS.

Indikator keefektifan yang terakhir adalah aktivitas guru. Aktivitas guru diamati melalui lembar pengamatan aktivitas guru. Aktivitas guru 
yang diamati mulai dari pra kegiatan, pendahuluan, kegiatan inti, kegiatan penutup, pendekatan dan strategi pembelajaran, pemanfaatansumber belajar, pembelajaran, penilaian proses dan hasil belajar dan penggunaan bahasa. Hasil pengamatan aktivitas guru selama tiga pertemuan diperoleh skor secara berurutan, yaitu; 34; 35; 35 dengan skor rata-rata 34,7 termasuk dalam rentang $(29 \leq \mathrm{Sa}<38)$ dengan kategori sangat baik.

Penggunaan perangkat pembelajaran kebencanaan alam bervisi SETS terintegrasi dalam IPA yang dikembangkan efektif untuk membelajarkan kebencanaan alam dan sains. ${ }^{10}$ Hal ini dapat dilihat dari ketuntasan belajar disetiap akhir pembelajaran, serta peningkatan pemahaman terhadap sains dan kebencanaan alam. Perangkat pembelajaran bervisi SETS yang dikembangkan menunjukkan sebanyak 83\% dari indikator pada silabus mempunyai validitas tinggi, untuk RPP dan bahan ajar indikator yang mempunyai tingkat kevalidan tinggi sebesar $89 \%$, sedangkan untuk petunjuk praktikum indikator yang mempunyai tingkat validitas tinggi sebesar $78 \%$.

Hasil N-gain untuk tes Kognitif menunjukkan peningkatan sebesar 0,85. ${ }^{11}$ Peningkatan ini tergolong kategori tinggi. Ditinjau dari hasil belajarnya secara keseluruhan, menunjukkan peningkatan hasil belajar. Nilai signifikan (2-tailed) yang diperoleh $0,0000<0,05$, menunjukkan bahwa terdapat peningkatan hasil belajar peserta didik secara signifikannifikan setelah pembelajaran dilakukan, dari data kriteria ketuntasan minimal sebanyak 29 peserta didik dari 32 pada kelas penelitian memperoleh nilai $>75$. Keaktifan peserta didik $78 \%$ termasuk kategori tinggi, menunjukkan nilai rata-rata (mean) setelah menggunakan

10 Rusilowati, A, Binadja, A, 2009,Mitigasi Bencana Alam Berbasis Pembelajaran Kebencanaan Alam Bervisi SETS Terintegrasi dalam Beberapa Mata Pelajaran, Laporan Penelitian Hibah, Semarang: Universitas Negeri Semarang

${ }^{11}$ Susena, 2011, Pengembangan Perangkat Pembelajaran Bervisi SETS untuk Membantu Mencapai Kompetensi Berkaitan dengan Larutan Penyangga, Tesis, Semarang: Program Pascasarjana Unnes 
pendekatan SETS dan keterlaksanaan mencapai $88 \%$ sehingga masuk kategori praktis.

Bahan ajar cetak terbukti efektif karena dalam pembelajaran guru dan peserta didik menggunakan bahan ajar cetak IPA bervisi SETS. Pembelajaran bervisi SETS merupakan visi atau cara pandang terhadap suatau permaslahan. Visi SETS sangat sesuai dengan materi yang dikembangkan, yaitu materi sumber daya alam. Guru mengajak peserta didik dalam memecahkan masalah berdasarkan unsur sains, lingkungan teknologi dan masyarakat. Selain itu peserta didik dimudahkan dan diajak mempraktekannya dengan kegiatan gerakan ayo menanam sayur. Kegiatan ini dilaksanakan di lingkungan sekitar sekolah, peserta didik diajak secara langsung menerapkan unsur-unsur SETS, yaitu 1) peserta didik mempelajari tumbuhan apa saja yang akan ditanam2) peserta didik mengidentifikasi dampak dan prasyarat apa saja yang diperlukan sesuai dengan kondisi lingkungan, 3) peserta didik mengidentifikasi teknologi yang digunakan dalam bercocok tanam dan 4) pengaruh kegiatan menanam sayur terhadap lingkungan sekolah.

Kegiatan diatas pernah dilakukan penelitiandengan judul Pengaruh pendekatan POE bervisi SETS pada pokok bahasan reaksi redoks terhadap hasil belajar peserta didik kelas $\mathrm{X}$ pada Home Schooling Kak Seto Semarang tahun ajaran 2010/2011. Hasil penelitian menyimpulkan bahwa rata-rata hasil belajar kelas eksperimen 89,9, sedangkan kelas kontrol 75,3. Hasil analisis data menunjukkan adanya pengaruh penggunaan POE bervisi SETS terhadap hasil belajar kimia. Konsep reaksi redoks peserta didik yang ditunjukkan dengan angka korelasi 0,602, dengan pengaruh $36,24 \%$ untuk hasil belajar, sedangkan aspek psikomotor praktikum 
peserta didik sebesar 39,85 aspek afektif peserta didik sebesar 140, 1825 dan aspek aktifitas peserta didik sebesar $43,175 .^{12}$

Pembelajaran di atas sangatlah cocok untuk mengembangkan keterampilan proses pada peserta didik yang dikaitkan dengan SETS. Pembelajaran SETS diawali dengan penemuan masalah kemudian menggunakan lingkungan dan masyarakat sebagai sumber belajar dan peserta didik aktif dalam memecahkan masalah. ${ }^{13}$ Efek dari pengembangan juga mempengaruhi cara mata pelajaran ilmu pengetahuan alam yang diajarkan. Pembelajaran dapat dijelaskan melalui ilmu pengetahuan, teknologi, masyarakat dan pendekatan pendidikan lingkungan (STSE).${ }^{14}$ Pembelajaran tidaklah cukup dilaksanakan di dalam kelas akan tetapi perlu adanya perpanjangan waktu untuk menyelesaikan tugas-tugas yang berkaitan dengan lingkungan dan masyarakat di luar jam belajar.

Pembelajaran tidaklah cukup dilaksanakan di dalam kelas, akan tetapi memerlukan pengalaman-pengalaman baru dalam meningkatkan hasil belajar. Pembelajaran semestinya dilaksanakan dengan multi inderawi seperti apa yang dikemukakan Howard Gardner dalam Armstrong delapan kecerdasan dasar adalah (1) Kecedasan linguistik (word smart), (2) kecerdasan logis-matematis (numbering smart), (3) kecerdasan spasial (picture smart), (4) kecerdasan kinestetik (body smart), (5) kecerdasan musikal (musical smart), (6) kecerdasan antgar pribadi (people smart), (7) kecerdasan intra pribadi (self smart), (8) kecerdasan

\footnotetext{
${ }^{12}$ Saputro dan Hadi Yanuar, 2011,Pengaruh Pendekatan POE Bervisi SETS,Tesis, Semarang: UNNES

${ }^{13}$ Yager, R. E, 2009,A Comparation of Students Learning in STS vsThose in Directed Inquary Classes,Journal ofScience Education and Technology. 13 (2) : 187.

${ }^{14}$ Yoruk, Inci Morgil, Nilgün Seçken, 2009, The effects of science, technology, society and environment (STSE) education on students' career planning, Journal US-China Education Review, ISSN 1548-6613. 6 (8) (Serial No.57)
} 
naturalis (naturalis smart). ${ }^{15}$ Peserta didik membutuhkan fasilitas untuk mengekspresikan setiap kecerdasannya. Kegiatan gerakan ayo menanam sayur merupakan kegiatan motorik yang dapat meningkatkan nilai kognitif dan afektif. Peserta didik diminta untuk mengidentifikasi cara-cara bercocok tanam kemudian merawatnya dan diajak untuk memiliki sikap peduli terhadap lingkungan.

Kegiatan menanam sayur disertai pemeliharaannya melatih peserta didik disiplin. Contohnya peserta didik secara berkala menyiram dan memberi pupuk, membersihkan gulma tanaman mengisi tabel pemeliharaan merupakan contoh kegiatan yang membangun karakter disiplin. GAMeS merupakan pembelajaran yang berbasis lingkungan hidup yang dikaitkan dengan unsur-unsur SETS. Pendidikan lingkungan hidup berfokus membantu peserta didik dalam pengembangan pengetahuan dan keterampilan serta sikap yang bertanggung jawab. ${ }^{16}$

\section{SIMPULAN}

Pengembangan Bahan Ajar Cetak IPA Bervisi SETS dalam Kompetensi Sumber Daya Alam Kelas IV Sekolah Dasar valid dan efektif: 1) Karakteristik bahan ajar cetak IPA bervisi SETS adalah menggabungkan antara materi sumber daya alam dengan unsur-unsur SETS, terdapat petunjuk penggunaan buku yang dilengkapi dengan peta konsep, standar kompetensi, kompetensi dasar, indikator, tujuan, informasi pertemuan ke berapa dalam bahan ajar, info SETS, diagram SETS, rangkuman, evaluasi, dan glosarium untuk memudahkan peserta didik mengetahui apa yang akan dipelajari. 2) Skor validasi 45; 44; 43 dan 45 jika dikonsultasikan pada tabel kriteria validitas bahan ajar cetak dalam kategori sangat baik. Keempat skor validasi

${ }^{15}$ Armstong, T, 2005,Setiap Anak Cerdas, Jakarta : PT Gramedia Pustaka Utama.

${ }^{16}$ Randall, L., Weisenmayer and Peter A. R, 1999, The effect of STS ISSUE Investigation an action versus traditional life science instruction seventh grade students citizenship behaviours, Journal of Science Education and Technology, 8 (2) : 137-144. 
bahan ajar cetak jika dirata-rata diperoleh skor nilai validasi 44 atau dalam kategori sangat baik. Skor kepraktisan dilihat dari hasil respons guru terhadap bahan ajar cetak menunjukkan skor 18 kategori sangat baik, karena terdapat dua respons negativ dari dua puluh indikator atau skor 18 berada di dalam rentang $(15 \leq \mathrm{Sa} \leq 20)$ dengan kategori sangat baik. Hasil respons peserta didik terdapat tiga kategori, yaitu 25 peserta didik kategori sangat baik, 3 peserta didik kategori baik dan 2 peserta didik kategori cukup. Respons peserta didik jika dikonsultasikan pada indikator keberhasilan penelitian diperoleh hasil/ kategori berhasil karena terdapat 25 peserta didik yang memberikan respons sangat baik. 3) Skor keefektifan dapat dilihat dari hasil belajar, ketuntasan hasil belajar, peningkatan hasil belajar, aktivitas guru dan aktivitas peserta didik.

Ketuntasan hasil belajar kelas eksperimen menunjukkan nilai terendah 57, nilai tertinggi 90 nilai rata-rata 79 dan jumlah peserta didik yang tuntas (KKM 70) sebanyak 26 dari 30 peserta didik. Hasil uji one sample t test menunjukkan harga $t_{\text {hitung }} 6,74>\mathrm{t}_{\text {table }}=1,729$ dengan demikian $\mathrm{H}_{0}$ diterima dan $\mathrm{H}_{\mathrm{a}}$ ditolak. Jadi dapat disimpulkan bahwa jumlah peserta didik yang memperoleh skor 70 adalah benar. Peningkatan hasil belajar kedua kelas diukur menggunakan uji $\mathrm{n}$ <gain>. Hasil uji peningkatan hasil belajar kelas eksperimen diperoleh skor $\langle\mathrm{g}\rangle=0,40$ dalam kategori sedang. Hasil pengamatan aktivitas peserta didik yang memperoleh skor dalam kategori tinggi pada pertemuan I sebanyak 28, pertemuan II sebanyak 29 dan pertemuan III sebanyak 29. Hasil pengamatana aktivitas guru selama tiga pertemuan diperoleh skor secara berurutan, yaitu; 34; 35; 35 dengan skor ratarata 34, 67 termasuk dalam rentang $(29 \leq \mathrm{Sa}<38)$ dengan kategori sangat baik.

Berdasarkan hasil dan pembahasan dalam penelitian pengembangan pembelajaran IPA SD bervisi SETS, disarankan: bahan ajar cetak IPA bervisi SETS dalam kompetensi sumber daya alam telah dikembangkan dengan hasil 
yang valid, efektif, dan praktis, maka perlu dilakukan uji coba dalam skala lebih luas dan Guru dapat menggunakan bahan ajar cetak IPA bervisi SETS ini sebagai suplemen untuk proses pembelajaran. 


\section{DAFTAR PUSTAKA}

Amelia, Wachyu. Karakteristik dan Jenis Kesulitan Belajar Anak Slow Learner, Jurnal Ilmu Kesehatan Aisyah, Volume 1 No. 2 Juli Desember 2016.

Armstong, T, Setiap Anak Cerdas.Jakarta : PT Gramedia Pustaka Utama, 2005.

Binadja, Achmad. (1999). Hakekat dan Tujuan Pada SETS (Science, Environment, Technology, And Society) Dalam Konteks Kehidupan Pendidikan Yang Ada. Makalah Seminar Lokakarya Pendidikan SETS 14-15 Desember 1999. Semarang: UNNES

Depdiknas, Kurikulum Tingkat Satuan Pendidikan (KTSP). Jakarta:Departemen Pendidikan Nasional, 2006.

Esa Nur Wahyunidan Baharuddin, Teori Belajar \& Pembelajaran, Jogjakarta: ArRuzz Media, 2010.

Randall, L., Weisenmayer and Peter A. R, "The effect of STS ISSUE Investigation an action versus traditional life science instruction seventh grade students citizenship behaviours". Journal of Science Education and Technology. 8 (2) : 137-144, 1999.

Rosario, B.,I, Science, Technology, Society, dan Evironment (STSE). Approach in Environment Science For Non Science Student in a local Culture. Volume. 6 No. 1 Desember 2009 ISSN: 20994-1064 CHED Accredited Research Journal, CategoryB, 2009.

Rusilowati, A, Binadja, A, Mitigasi Bencana Alam Berbasis Pembelajaran Kebencanaan Alam Bervisi SETS Terintegrasi dalam Beberapa Mata Pelajaran. Laporan Penelitian Hibah. Semarang: Universitas Negeri Semarang, 2009.

Rusman, Model-model Pembelajaran. Jakarta:PT. Raja Grafindo Persada, 2010. 
Saputro dan Hadi Yanuar., Pengaruh Pendekatan POE Bervisi SETS. Tesis. Semarang: UNNES, 2011.

Susena, Pengembangan Perangkat Pembelajaran Bervisi SETS untuk Membantu Mencapai Kompetensi Berkaitan dengan Larutan Penyangga, Tesis. Semarang: Program Pascasarjana UNNES, 2011

Viola, S. R., giretti, A. and leo, T, Detecting Differences in "Meaningful Learning" Behaviours and their Evaluation: a Data Driven Approach. International Journal of Computing \& Information Science. 5 (2): 6373, 2007.

Wijayama, B, Pengembangan Perangkat Pembelajaran IPA Bervisi SETS dengan Pendekatan SAVI untuk Meningkatkan Keefektifan Pembelajaran dan Pembentukan Karakter Peserta Didik Sekolah Dasar, Tesis, Semarang: Program Pascasarjana Unnes, 2013.

Yachya, Hasyim, Tentang anak berkebutuhan khusus. Jakarta: 2013.

Yager, R. E, "A Comparation of Students Learning in STS vsThose in Directed Inquary Classes". Journal ofScience Education and Technology. 13 (2) : 187, 2009.

Yoruk, Inci Morgil, Nilgün Seçken, "The effects of science, technology, society and environment (STSE) education on students' career planning". Journal US-China Education Review, ISSN 1548-6613. 6 (8) Serial No.57,2009. 